\title{
Averrhoa carambola leaf from Depok, West Java, Indonesia: Phytochemistry characterization and prospective anti-candidiasis activity
}

\author{
Marina Ika Irianti ${ }^{1}$ D, Berna Elya ${ }^{2 *}$, Ratika Rahmasari ${ }^{1}$, Nuraini Puspitasari ${ }^{2}$, Fasya Hadaina Maharani ${ }^{2}$, \\ Muhareva Raekiansyah ${ }^{3}$ \\ ${ }^{1}$ Laboratory of Microbiology and Biotechnology, Faculty of Pharmacy, Universitas Indonesia, Depok, Indonesia. \\ ${ }^{2}$ Laboratory of Pharmacognosy and Phytochemistry, Faculty of Pharmacy, Universitas Indonesia, Depok, Indonesia. \\ ${ }^{3}$ Helix Laboratory, Depok, West Java, Indonesia.
}

\section{ARTICLE INFO \\ Received on: $10 / 12 / 2020$ \\ Accepted on: 13/05/2021 \\ Available Online: 05/01/2022}

Key words:

Candida albicans, Averrhoa

carambola leaves, crystal

violet, anti-candidiasis,

MTT assay.

\begin{abstract}
Candida albicans is a commensal microorganism that can be pathogenic in immunocompromised patients. Eradication of candidiasis is complicated by the resistance of the existing antifungal agents. Therefore, novel antifungal drug discovery is required for the efficient management of candida infections. The invention of antifungal from natural products has been stimulated by the increasing prevalence of drug resistance. The aim of this study is to evaluate the antifungal activities of Averrhoa carambola leaves, an Indonesian native plant. The antifungal activity was evaluated by conducting crystal violet (CV) and 3-(4,5-dimethylthiazol-2-yl)-2,5-diphenyl-2H-tetrazolium bromide (MTT) assay to determine $\mathrm{IC}_{50}$ values. From the initial screening, the ethyl acetate fraction of $A$. carambola leaves showed inhibition against $C$. albicans growth. According to the microscopic observations, trichome was presented in both the upper and lower sides of the $A$. carambola leaves. The CV assay result confirms that $C$. albicans cells supplemented by the extract grew lower than the untreated cells by reaching more than $60 \%$ cell reduction compared to control. The MTT assay was carried out to assess the inhibitory effect on the cell viability $\left(\mathrm{IC}_{50}=24 \mu \mathrm{g} / \mathrm{ml}\right)$. The thin layer chromatography results showed flavonoid and steroid contents in A. carambola leaves. The presence of flavonoid and steroid was subsequently confirmed by using liquid chromatographytandem mass spectrometry which showed two compounds, namely pinocembrin-7-neohesperidoside and spinasterol. This preliminary study indicated that $A$. carambola leaves are potential for anti-candidiasis drug development.
\end{abstract}

\section{INTRODUCTION}

Candida albicans is an opportunistic fungal pathogen that is present in about $70 \%$ of the human population as commensal in the gastrointestinal and genitourinary tracts. Approximately $75 \%$ of women suffer from candida infection at least once in their lifetime (Meiller et al., 2009; Rosenfeld, 2009). In the past few decades, it is reported that the occurrence of candidiasis infection has been increased significantly, as well as the resistance of azole antifungal against several Candida species (Whaley et al., 2017).

*Corresponding Author

Berna Elya, Laboratory of Pharmacognosy and Phytochemistry,

Faculty of Pharmacy, Universitas Indonesia, Depok, Indonesia. E-mail:

berna.elya@farmasi.ui.ac.id
Several factors that contribute to the pathogenicity and infection of $C$. albicans are adhesion, alteration from fungi (yeast) to the filament (hyphae), and generation of extracellular enzymes, such as aspartyl proteinase, which is related to pathogenicity (Naglik et al., 2003).

The severity of candidiasis is affected by some causes, such as immunocompromised condition, chemotherapy, comorbidities with diabetes, the extensive use of broad-spectrum antibiotics, and aging (Pierce and Lopez-Ribot, 2013). Unfortunately, the higher incidence of candidiasis infection is not followed by the higher rate of antifungal drug discovery. The limitation of developing antifungal drugs is the difficulties in identifying the specific target for drug discovery, also most antifungal drugs have higher toxicity because they target the fungal cells, which are also eukaryotic (Pierce and Lopez-Ribot, 2013). Therefore, the invention of new 
antifungal drugs has remained stagnant for the last few years. In addition, the pharmaceutical industries have placed more attention on finding the COVID-19 vaccine rather than antifungal discovery for the last year, which is urgently needed to tackle the global pandemic.

Natural products are worthy materials for the drug discovery study since they possess a wide range of structural and functional diversities, which are useful for treating diseases (Newman and Cragg, 2016). Among varied sources of natural products, plants are important sources for new drug development. Plants as remedies are gaining popularity in consecutive years. As one of the most megadiverse countries in the world, Indonesia has a large number of flora species that are potentially used as medicinal herbal plants. In this study, we carried out the microscopic characterization of Averrhoa carambola leaves, an Indonesian native plant, and tried to assess their bioactivity as antifungal drugs. The potential antifungal activities of the ethyl acetate fraction from $A$. carambola leaves were evaluated by crystal violet $(\mathrm{CV})$, followed by MTT assay. To validate the potential phytochemical contents, we subsequently carried out the flavonoid and steroid detection assays by using thin layer chromatography (TLC) and advanced analysis by liquid chromatography-tandem mass spectrometry (LC-MS/MS).

\section{MATERIALS AND METHODS}

\section{Materials}

Averrhoa carambola leaves were obtained from Depok, West Java, Indonesia. Candida albicans (Universitas Indonesia Culture Collection) were cultured in the potato dextrose agar (PDA) medium (Wako, Japan) at $28^{\circ} \mathrm{C}$, dimethyl sulfoxide (DMSO) (Merck Millipore, Germany), fetal bovine serum (FBS) (Sigma Aldrich), sodium dextrose broth (SDB) (BD Difco), ethyl acetate (Merck Millipore, Germany), CV (Merck Millipore, Germany), MTT (Sigma Aldrich), and Fluconazole (Sigma Aldrich).

\section{Microscopic identification of $\boldsymbol{A}$. carambola leaves}

Averrhoa carambola leaves were determined and identified at the Center for Plant Conservation Botanical GardensIndonesian Institute of Sciences [Lembaga Ilmu Pengetahuan Indonesia (LIPI)], Bogor. The leaves were observed under the Nikon Eclipse E200 microscope $(10 \times$ and $40 \times)$. Before the observation, the leaves were horizontally and vertically sliced to evaluate the cell characteristics. For advance analysis, the powder of dried leaves was observed under the scanning electron microscope (SEM) JSM-IT200.

\section{Extract preparation}

The extraction and fractionation procedures of A. carambola leaves were carried out as that described in a previous study by Nabilah et al. (2017). Firstly, the leaves were cleaned, dried in room temperature for 5 days, and milled in an electric blender. The dried leaves were then powdered by using a milling machine. The powdered simplicia were extracted by maceration with $70 \%$ ethanol. After 24 hours, the solvent was removed, and the extract was evaporated by using a rotary vacuum evaporator $\left( \pm 50^{\circ} \mathrm{C}\right)$. The ethanol extract was fractioned with $\mathrm{n}$-hexane, ethyl acetate, and water. The fraction was evaporated again by a rotary vacuum evaporator $\left(40^{\circ} \mathrm{C}, 100 \mathrm{rpm}\right)$. The ethyl acetate fraction was subsequently used in the assays.

\section{Anti-C. albicans activity of $A$. carambola leaves}

\section{Sample and inoculum preparation}

In brief, approximately $30 \mathrm{mg}$ of $A$. carambola ethyl acetate fractions were dissolved in $100 \mu \mathrm{l}$ of DMSO. Then, the extract solution was diluted with SDB and put into each well with the highest DMSO concentration of $1 \%$. The anti-C. albicans assay was carried out in a 96-well culture plate which was coated with $50 \%$ FBS. Candida albicans were cultured in the PDA medium at $28^{\circ} \mathrm{C}$; then the cells were grown overnight in SDB. The cell pellet was diluted in phosphate buffer saline (PBS) at a cell density of $5 \times 10^{9} \mathrm{cell} / \mathrm{ml}$, aseptically.

\section{CV assay}

The CV assay was carried out by adding $100 \mu \mathrm{l}$ of the extract in SDB and $100 \mu \mathrm{l}$ of $C$. albicans $3 \times 10^{4}$ cells/well in a $96-w e l l$ plate. The plates were then incubated at $28^{\circ} \mathrm{C}$ for 2 days. After incubation, $150 \mu \mathrm{l}$ of supernatant was aspirated and the cells were washed by $100 \mu \mathrm{l}$ of PBS. Immediately after washing, 100 $\mu \mathrm{l}$ of ethanol was added and incubated for 1 hour at $4^{\circ} \mathrm{C}$. As much as $100 \mu \mathrm{l}$ of $\mathrm{CV}$ was added in 96-well microplates and incubated for 15 minutes. Then, CV was aspirated and the plate was washed with water. The next day, the microplate was added by $100 \mu \mathrm{l}$ ethanol $96 \%$ and read in the microplate reader $(\lambda=490 \mathrm{~nm})$. Data are represented as the mean \pm standard error from two independent experiments (each in triplicate).

\section{MTT assay}

The MTT assay was executed in a 96-well plate of cell culture and sample. The effect of $A$. carambola leaves was evaluated by putting $100 \mu \mathrm{l}$ of samples (with $1 \%$ DMSO concentration) in a coated 96-well plate, followed by the addition of $5 \times 10^{6}$ cells $/ \mathrm{ml}$. The plate was incubated for 24 hours at $28^{\circ} \mathrm{C}$. After overnight incubation, the medium was aspirated to $150 \mu \mathrm{l}$ and washed with $100 \mu \mathrm{l}$ of PBS. Then, $40 \mu \mathrm{l}$ of MTT was put in the well plate and incubated for 2 hours at $28^{\circ} \mathrm{C}$. The MTT reagent was made of $5 \mathrm{mg}$ MTT in $1 \mathrm{ml}$ of sterile water, then diluted in $0.15 \mathrm{M}$ of sterile PBS with a ratio $1: 5$. The absorbance was measured by a spectrophotometer reader $(\lambda=540 \mathrm{~nm})$. The $\mathrm{IC}_{50}$ was calculated according to the MTT assay. The samples were prepared in twofold dilution conditions (triplicate). The $\mathrm{IC}_{50}$ was analyzed by GraphPad Prism 9.

\section{Phytochemical screening by TLC}

\section{Flavonoid detection assay}

The crude extract of $A$. carambola leaves was diluted with $5 \mathrm{ml}$ ethanol. The mixture was homogenized by sonification for 30 minutes. The end concentration of dilution was $10,000 \mathrm{ppm}$. Quercetin was used as a standard in this assay. As much as $10 \mu \mathrm{l}$ of sample and the standard solution were analyzed with TLC silica gel 60 F254, and then developed with the chloroform:acetone:formic acid (8:2:1) mobile phase. After development, the TLC plate was sprayed with $\mathrm{AlCl}_{3} 5 \%$ and then observed on UV lamp $366 \mathrm{~nm}$ for flavonoid identification. 
Table 1. Solvent gradient for UPLC analysis. Composition A consisted of $0.1 \%$ formic acid/water and composition B consisted of acetonitrile $+0.1 \%$ formic acid with a flow rate at $0.3 \mathrm{ml} /$ minute.

\begin{tabular}{ccccc}
\hline Time (minute) & $\begin{array}{c}\text { Flow rate } \\
(\mathbf{m l} / \text { minute) }\end{array}$ & $\begin{array}{c}\text { Composition A } \\
\mathbf{( \% )}\end{array}$ & $\begin{array}{c}\text { Composition B } \\
(\mathbf{\%})\end{array}$ & Curve \\
\hline 0.00 & 0.300 & 95.0 & 5.0 & Initial \\
1.00 & 0.300 & 95.0 & 5.0 & 6 \\
8.00 & 0.300 & 60.0 & 40.0 & 6 \\
11.00 & 0.300 & 0.0 & 100.0 & 1 \\
13.00 & 0.300 & 0.0 & 100.0 & 1 \\
16.00 & 0.300 & 95.0 & 5.0 & 1 \\
\hline
\end{tabular}

\section{Steroid detection assay}

$10 \mu \mathrm{l}$ of sample and standard solution ( $\beta$-sitosterol 100 ppm) were analyzed with TLC silica gel 60 F254 and developed with hexane:ethyl acetate (4:1) mobile phase. Then, TLC plate was sprayed with anisaldehyde-sulfuric acid and then heated to $105^{\circ} \mathrm{C}$. Violet color in the TLC plate indicated the presence of steroids.

\section{Phytochemical identification by LC-MS/MS}

The ethyl acetate fraction of A. carambola was analyzed using LC-MS/MS to predict the compounds presented in the fraction. The sample was analyzed by Acquity ultra performance liquid chromatography (UPLC) I-Class and XEVO G2-XS QTof. The column used for liquid chromatography

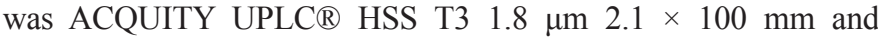
gradient solvent for elution was used as Table 1 . The condition of testing was stated as follows, full scan at $100-1,200 \mathrm{~m} / \mathrm{z}$ with Electrospray ionization (ESI) + Mode, column temperature at $40.0^{\circ} \mathrm{C}$, and sample temperature at $20.0^{\circ} \mathrm{C}$. The cone voltage and collision energy used were $30 \mathrm{~V}$ and $6.00 \mathrm{eV}$ [Low Capillary electrophoresis (CE)], 10.00-40.00 eV (High CE), respectively. Capillary was set at $1.5 \mathrm{kV}$ and source temperature was at $120^{\circ} \mathrm{C}$. The desolvation temperature was $500^{\circ} \mathrm{C}$. The cone gas flow and desolvation gas flow were each at 50 and 1,000 1/hour.

\section{RESULTS}

\section{Microscopic identification of $A$. carambola leaves}

To identify the specific fragments in plants, dried powder of $A$. carambola leaves was observed with SEM. Each plant tissue has specific fragments that differ from other species. As can be seen in Figure 1A, the microscopic identification shows a vascular bundle with node type. Trichome can be observed in Figure 1B

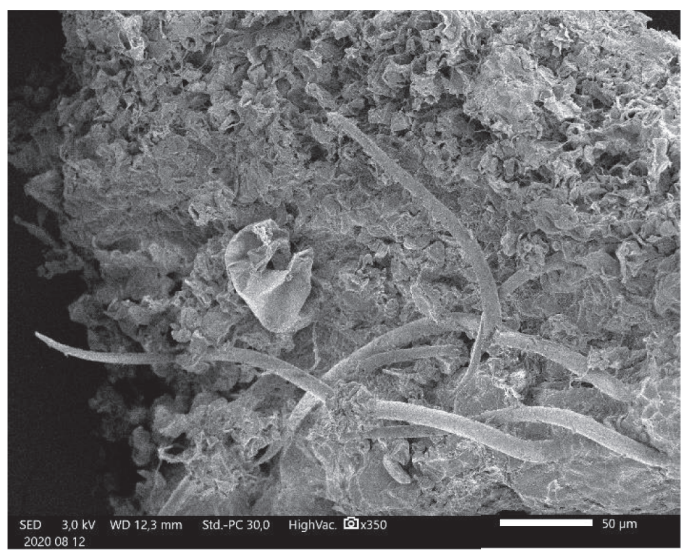

(b)
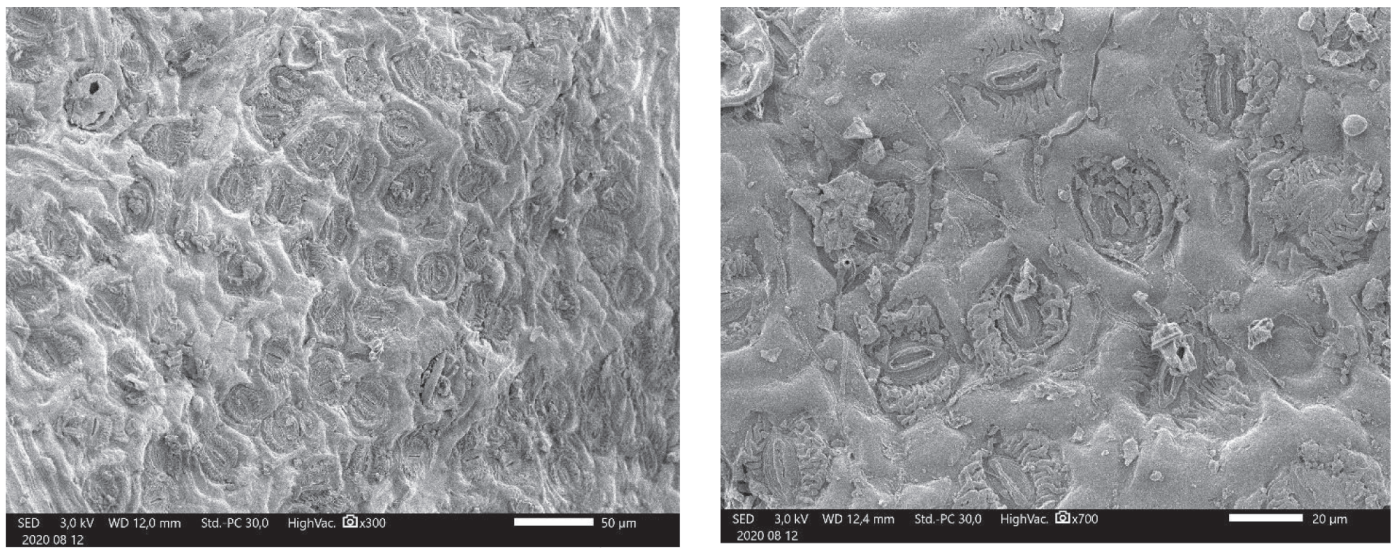

(c) (d)

Figure 1. Powder of dried leaves of $A$. carambola observed by SEM (a) vascular bundle, (b) trichome, (c) stomata 300×, and (d) stomata $700 \times$. 


\section{Crystal Violet Assay}

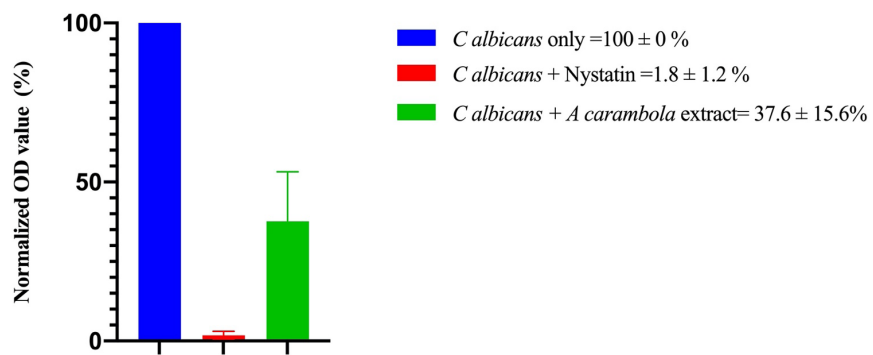

Figure 2. The CV assay of ethyl acetate extract of A. carambola (leaf) extracts against $C$. albicans growth. Data are represented as the mean \pm standard errors (each in triplicate). The tested nystatin concentrations were in a range of $0.2-25$ $\mathrm{UI} / \mathrm{ml}$ (two times dilution).

\section{Inhibitory action of $\boldsymbol{A}$ carambola extract in $\boldsymbol{C}$ albicans}

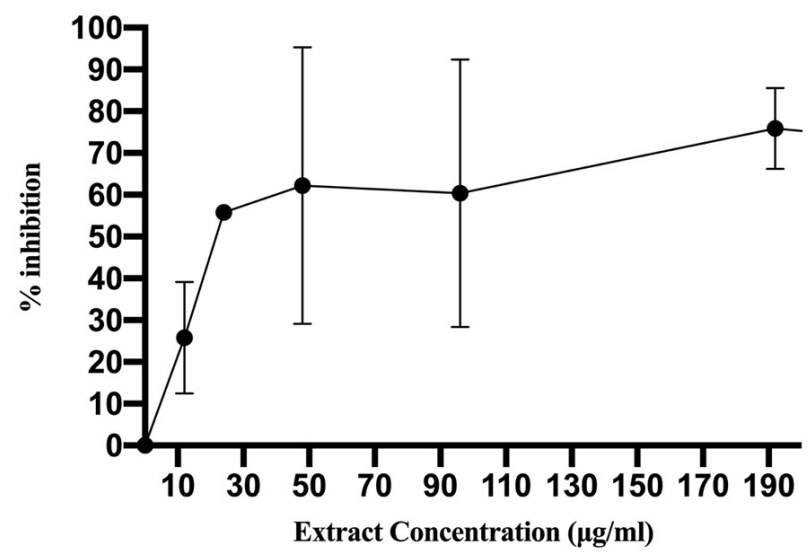

(a)

Inhibitory action of Nystatin in C albicans

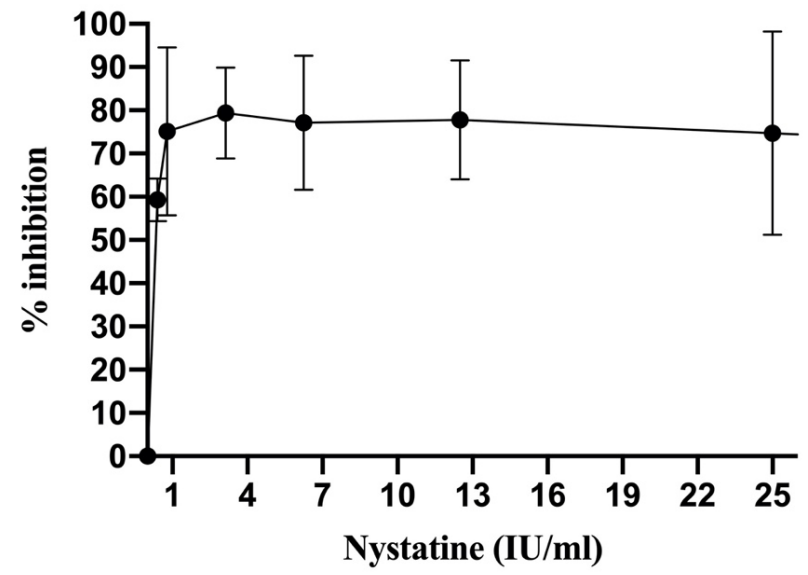

(b)

Figure 3. The effect of ethyl acetate extract of $A$. carambola (leaf) against C. albicans. (a) More than $50 \%$ reduction of $C$. albicans cell viability in the presence of ethyl acetate extract (maximum 1\% DMSO) at a concentration of more than $30 \mu \mathrm{g} / \mathrm{ml}\left(\mathrm{IC}_{50}=24 \mu \mathrm{g} / \mathrm{ml}\right)$. (b) The reduction of C. albicans cell viability (more than 50\%) in the presence of twofold dilution of nystatin at a concentration of less than $1 \mathrm{UI} / \mathrm{ml}$ (equal to $0.333 \mu \mathrm{g} / \mathrm{ml}$ ). Data are represented as the mean \pm standard error of the mean from two independent experiments (each in triplicate). and shows one cell type of trichome. Figure 1B also shows xylem fragment with spiral shape and trichome with one cell. Trichomes were attached in both the upper and lower epidermis, but more was observed in the upper epidermis. Stomata were observed in the lower epidermis (Fig. 1C and D) and showed anomocytic type, which has two or more guard cells from stomata. Upper epidermis cell lined in polygonal type, with some trichomes attached. Stomata in the lower epidermis were also captured and different magnifying size was used to observe stomata in a different scale (Fig. 1C and D).

\section{Anti-candidiasis activity assay of $\boldsymbol{A}$. carambola leaves}

CV assay

The CV assay was used to identify the inhibitory activity of $A$. carambola against $C$. albicans growth. The ethyl acetate extract of $A$. carambola (leaves) exhibited pronounced inhibition on Candida growth as determined from the reduction of optical density (OD). Normalized OD value shown in Figure 2 represents the abundance of cells in the microplate. The addition of ethyl acetate extract of $A$. carambola (leaves) significantly reduced cell growth by reaching over $60 \%$ as compared to untreated control in two independent experiments, while nystatin inhibited $C$. albicans growth by $90 \%$ as a positive control with the concentration of more than $1 \mathrm{IU} / \mathrm{ml}(1 \mathrm{IU}=0.000333)$ (Lightbown et al., 1963)

\section{MTT assay}

The antifungal activity of $A$. carambola leaves extract was further evaluated through cell viability assay. The MTT reagent was used to assess the metabolic activity in living microorganisms. The cell viability was assessed along with a serially diluted concentration of the extract. The data were shown in the $\mathrm{IC}_{50}$ value, which is the lowest concentration capable of inhibiting half of the cells' growth. As shown in Figure 3, the ethyl acetate extract of $A$. carambola leaves

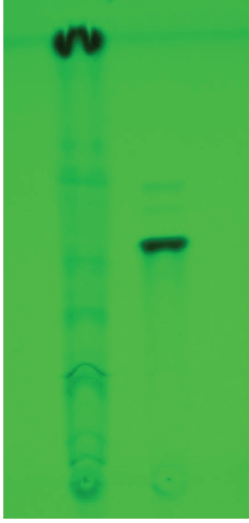

(a)

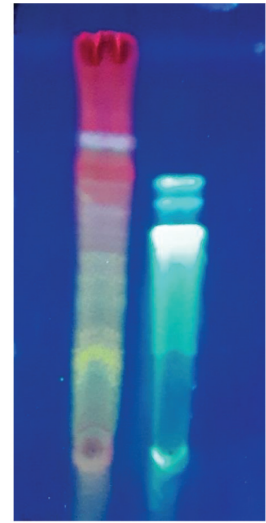

(b)

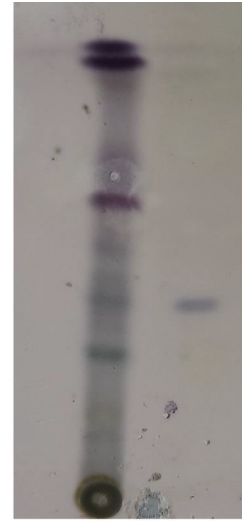

(c)
Figure 4. Flavonoid profile of ethyl acetate extract of $A$. carambola leaves by TLC after spraying with $\mathrm{AlCl}_{3}$ reagent at (a) UV $254 \mathrm{~nm}$; (b) UV $366 \mathrm{~nm}$ with mobile phase: chloroform:acetone:formic Acid (8:2:1) and stationary phase: TLC silica gel F254; (c) Betasitosterol profile of ethyl acetate extract of $A$. carambola leaves by TLC of after spraying with anisaldehid reagent, heated at $105^{\circ} \mathrm{C}$, with mobile phase: Toluen:ethyl acetate (4:1) and stationary phase: TLC Silica Gel F254. 
showed inhibitory activity against $C$. albicans with an $\mathrm{IC}_{50}$ value of $24 \mu \mathrm{g} / \mathrm{ml}$.

\section{Phytochemical screening by TLC}

The TLC development with chloroform:acetone:formic acid $(8: 2: 1)$ mobile phase in Figure 4 showed no occurrence of quercetin. However, the presence of other flavonoids was detected by greenish blue fluorescence. The flavonoids appeared to be in glycosides form, observing the fluorescence spots mostly still remained below quercetin spot. These flavonoids were obtained because the extraction process used ethanol $70 \%$ as solvent. The chromatogram obtained from TLC with hexane: ethyl acetate development in silica gel 60F254 showed occurrence of $\beta$-sitosterol in the extract. Moreover, some steroids were also detected in this chromatogram which spots turned into violet after plate was sprayed with anisaldehyde-sulfuric acid.

\section{Phytochemical identification by LC-MS/MS}

According to the LC-MS/MS analysis, the ethyl acetate fraction of $A$. carambola contains Pinocembrin-7-neohesperidoside $\left(\mathrm{C}_{27} \mathrm{H}_{30} \mathrm{O}_{13}\right)$ and Spinasterol $\left(\mathrm{C}_{29} \mathrm{H}_{48} \mathrm{O}\right)$. Figures 5 and 6 show both compounds were detected with mass 563.1765 and $413.3772 \mathrm{~m} / \mathrm{z}$, respectively. The shown retention time of liquid chromatography for each pinocembrin-7-neohesperidoside and spinasterol was 5.65 and 10.48 minutes, respectively.

\section{DISCUSSION}

Pharmacognosy assessment was conducted to apply the standardization method of natural products. A microscopic assay of $A$. carambola was observed to detect the authenticity of this plant (Kumar et al., 2011). Specific fragments will determine the identity of specific plants. In this study, the shape and types of trichome, stomata, and vascular bundle are shown as specific fragments owned by $A$. carambola. One of the standardization

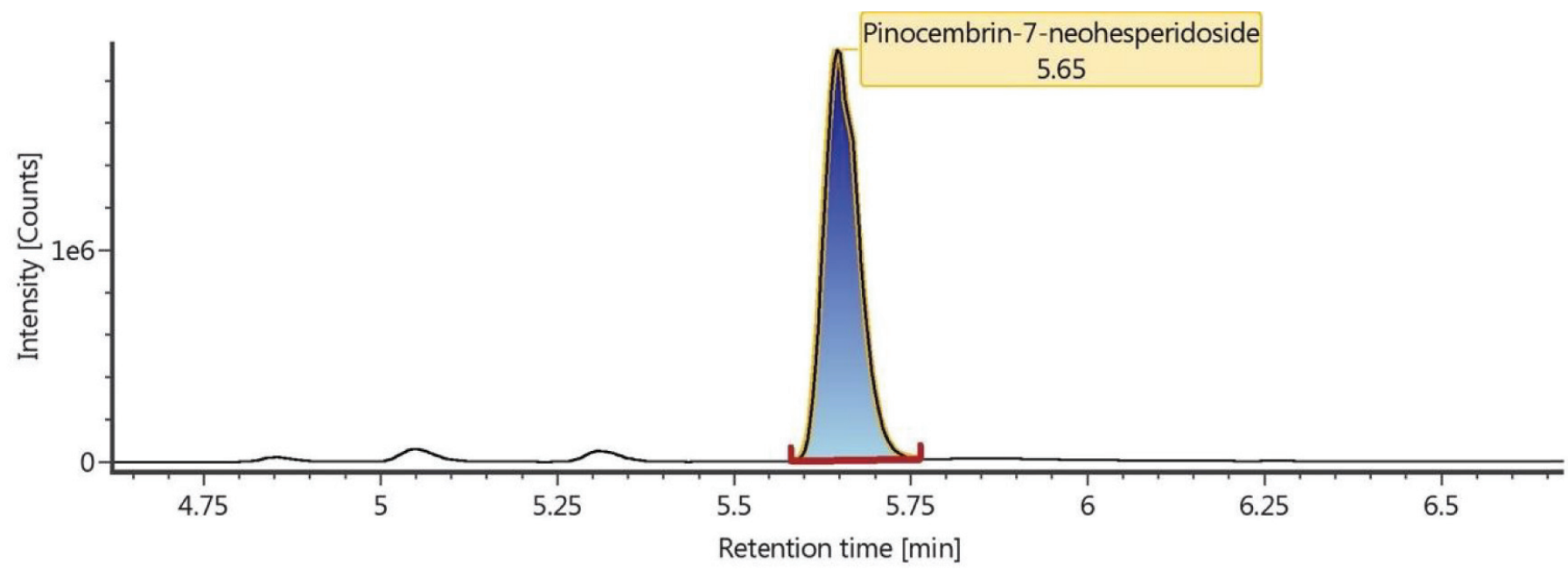

Item name: $210225-0388$

Channel name: Low energy : Time $5.6511+/-0.0256$ minutes

Item description:

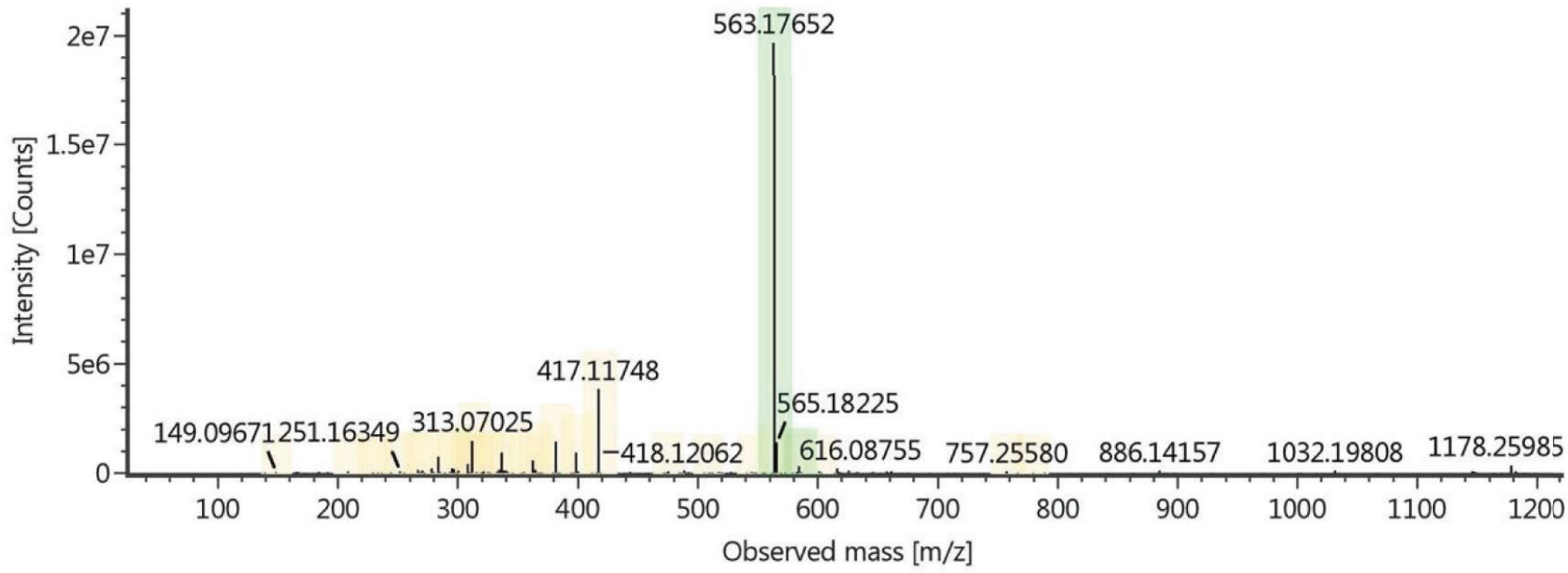

Figure 5. The peak of pinocembrin-7-neohesperidoside showed at 5.65 minutes by using liquid chromatography analysis (a) and observed mass $\mathrm{m} / \mathrm{z}$ of pinocembrin-7neohesperidoside obtained from time-of-flight mass spectrometry (TOF MS) ESI+ analysis (b). 
Item name: $210225-0388$

Channel name: 1: +413.3772 (36.4 PPM) +414.3804 (36.4 PPM) +415.3831 (36.4 PPM) +416.3855 (36.4 PPM) : TOF MS (50-1200) 6eV

ESI+ - Low CE : Integrated : Smoothed

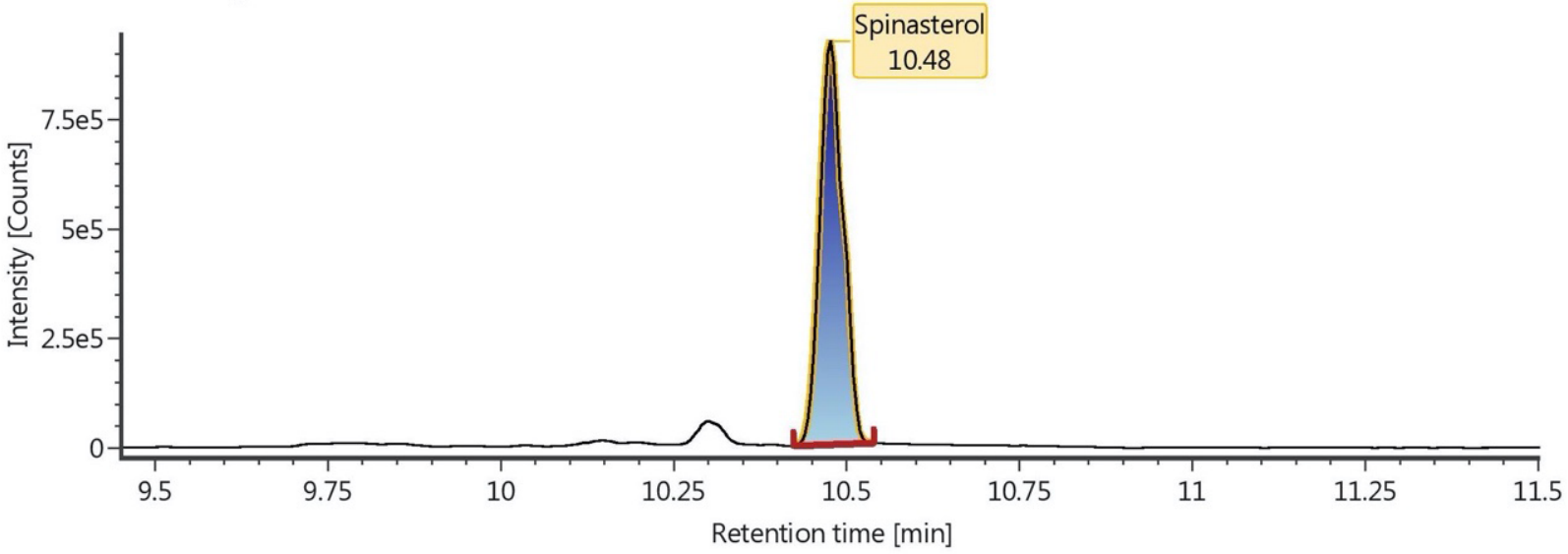

Item name: $210225-0388$

Channel name: Low energy : Time $10.4780+/-0.0256$ minutes

Item description:

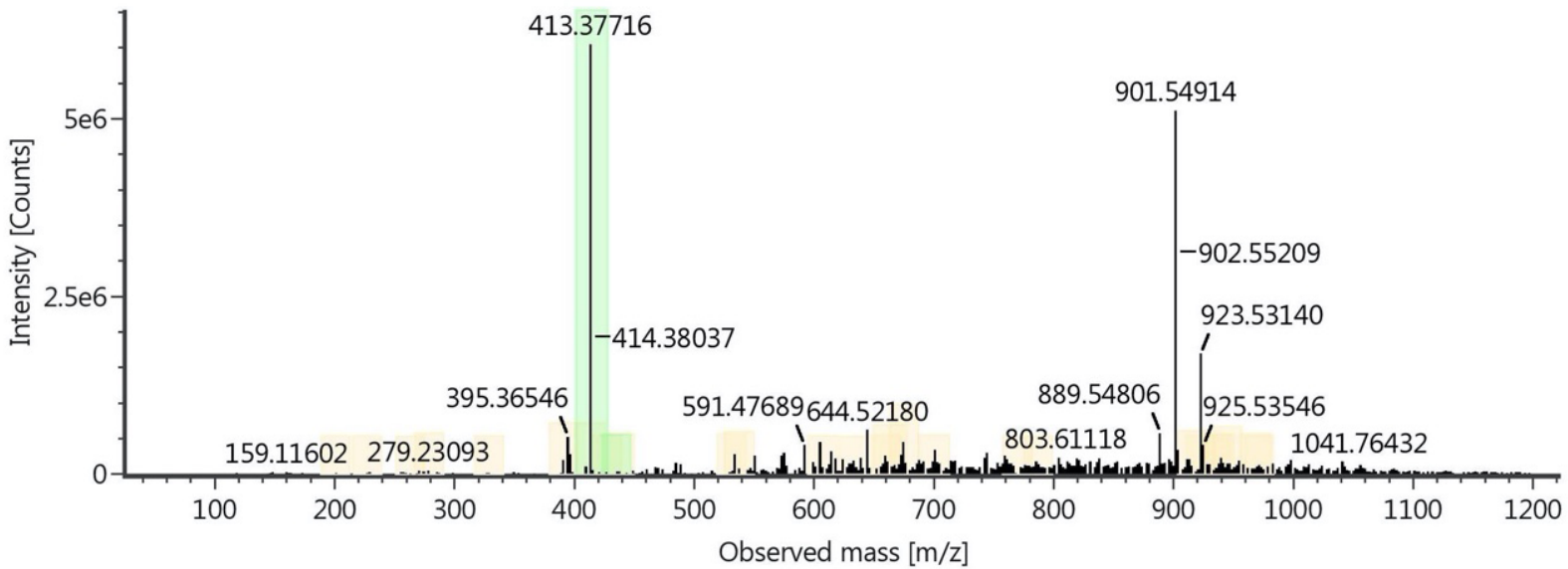

Figure 6. The peak of spinasterol showed at 10.48 minutes by using liquid chromatography analysis (a) and observed mass $\mathrm{m} / \mathrm{z}$ of spinasterol obtained from TOF MS ESI+ analysis (b).

processes with TLC methods was carried out to obtain a specific fingerprint of chromatogram pattern (Ramawat and Merillon, 2008). This study also showed the occurrence of flavonoids and steroids in leaves of $A$. carambola.

Candida albicans, which are presented as normal microbiota in human, may lead various infections in the immunocompromised patient, such as oropharyngeal (Redding et al., 1999) and vulvovaginal candidiasis (Fidel, 1998). The high morbidity rate due to candidiasis indicates the ineffectiveness of the existing therapies. Therefore, the invention of novel antifungal has been studied worldwide to combat fungal infections. In this case, the development of anti-virulence drugs targeting filamentation and biofilm formation is considered as a promising strategy for combating candida infections (Pierce and Lopez-Ribot, 2013). Another approach is creating compounds that act as antifungals by disrupting ion homeostasis (Li et al., 2018). For the last decades, the azole groups are the most commonly used antifungal to treat candidiasis, including posaconazole, imidazoles (clotrimazole, miconazole, and ketoconazole), and triazoles (itraconazole, fluconazole, and voriconazole) (Santos et al., 2018). However, the increase in drug resistance has encouraged researchers to invent novel antifungal. Medicinal plants have gained much interest in their potential sources of active compounds, such as flavonoids, coumarins, saponins, terpenoids, lectins, and tannins (Monteiro and Santos, 2019). The phytochemical screening of $A$. carambola has been studied for its pharmacological activities. However, the potency of $A$. carambola leaves against $C$. albicans has not been understood yet. In this study, we adopted the CV and MTT assay as a quick and cheap technique to evaluate the anti-candidiasis activity of $A$. carambola (leaves) extract.

$\mathrm{CV}$ is usually used to measure the biofilm mass of the cells. Principally, the dye from CV will stain the polysaccharide in the adherent cells and the absorbance is measured by spectrophotometer. Therefore, we developed this method in the initial screening step to find the potential activity of phytochemical extracts against biofilm formation in C. albicans. Our data 


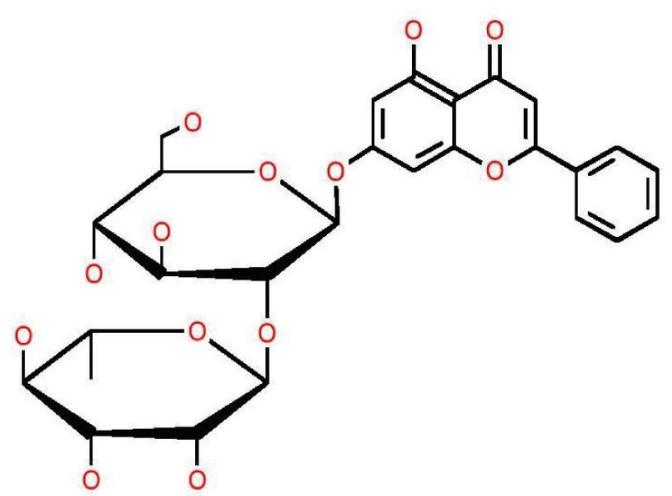

A

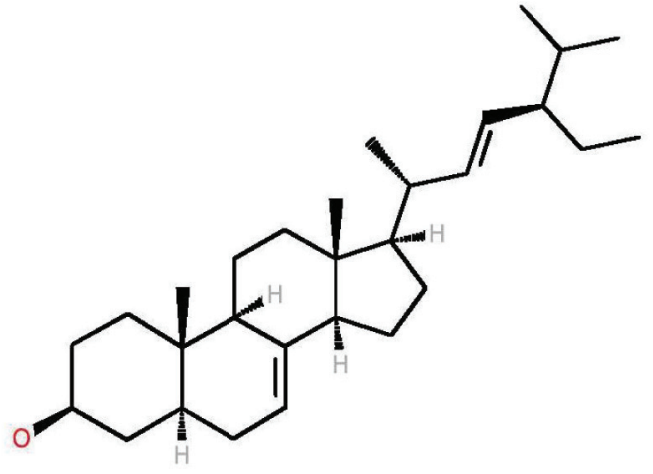

B

Figure 7. Chemical structure of pinocembrin-7-neohesperidoside (A) and spinasterol (B).

showed that among all extracts tested, the ethyl acetate extract of $A$. carambola inhibits the growth of $C$. albicans according to the $\mathrm{CV}$ assay. The inhibition was shown by the reduction of cell density, as compared to the untreated control, measured by the spectrophotometer method.

In addition to the $\mathrm{CV}$ assay, MTT assay was carried out for further examination of antifungal activity of $A$. carambola leaves. In principle, MTT assay is used to assess the cell viability based on the ability of metabolically active cells to convert tetrazolium salt into formazan, which gives purple color. The dead cells will not be capable of altering the tetrazolium salt and result in lower absorbance when compared to the viable cells. The results from both CV and MTT assay indicated that the leaves of A. carambola possess potent inhibitory activity and act as a promising source to be used as anti-candidiasis. Several phytochemical constituents present in A. carambola leaves, such as alkaloids, flavonoids, terpenoids, glycosides, quinones, and phlobatannin (Mewara et al., 2017) could potentially contribute to the antifungal activity of $A$. carambola leaves against $C$. albicans. Among these compounds, flavonoid derivatives have been widely studied for its antibacterial or antifungal activity (Poongodi and Nazeema, 2016).

The presence of flavonoid in ethyl acetate extract of $A$. carambola leaves was confirmed by TLC and advanced LC-MS/ MS method. Flavonoids are aromatic compounds containing 15 carbon atoms, which consist of 2 aromatic rings (Lopes et al., 2017). The examples of flavonoid derivatives are flavones (e.g., apigenin, luteolin), isoflavones, flavonols (e.g., kaempherol, quercetin), flavan-3-ols (catechin, epicatechin gallate), flavanon3-ols, flavonones, and chalcones (Cushnie and Lamb, 2005). It has been known that the highest apigenin and quercetin levels are present in the ethyl acetate fraction of $A$. carambola leaves (Yunarto and Sulistyaningrum, 2017). Besides its antibacterial activity, apigenin (4',5,7-trihydroxyflavone) is a naturally occurring phytochemical, which are also recognized as an antioxidant (Salehi et al., 2019).

The LC-MS/MS analysis supports the identification process of phytochemical compounds by observing the ratio of mass and charge number of ions $(\mathrm{m} / \mathrm{z})$ and comparing it with the recorded library database. This analysis showed that there are two compounds that might be responsible to antifungal activity of $A$. carambola leaves, namely pinocembrin-7-neohesperidoside and spinasterol, as shown in Figure 7. Pinocembrin-7-neohesperidoside is a flavonoid which commonly founded in A. carambola, Litchi chinnensis (Xu et al., 2011), and propolis (Governa et al., 2019). Many studies have been conducted to analyze its pharmacological effect. This flavonoid showed antimicrobial activity against $C$. albicans by inhibiting glucosyl transferase enzymes (Rasul et al., 2013). Moreover, a previous study reported that pinocembrin inhibited some Gram-negative and Gram-positive bacteria by determining minimal inhibitory concentration (Rasul et al., 2013). Besides having antimicrobial properties, pinocembrin showed antihypertension activity by inhibiting cardiac calcium current mechanism (Scholz et al., 2010) and acted as an antioxidant (Xu et al., 2011). Another phytochemical compound detected in LCMS/MS was the steroidal compound, spinasterol, known with its antitumor and anticarcinogenic activity. It is reported previously that spinasterol isolated from Erigeron sumatrensis leaves showed antimicrobial activity against Pseudomonas aeruginosa, Escherichia coli, and C. albicans (Ragasa et al., 2009).

In this study, the ethyl acetate fraction of A. carambola leaves inhibit half of the cell growth with a concentration of $24 \mu \mathrm{g} / \mathrm{ml}$. This inhibitory concentration is categorized as good, as the required concentration lower than $100 \mu \mathrm{g} / \mathrm{ml}$ (Zida et al., 2017). Related to the antimicrobial activity, it has been known that the good $\mathrm{IC}_{50}$ value of extracts was below $100 \mu \mathrm{g} / \mathrm{ml}$, while $25 \mu \mathrm{M}$ was the ideal concentration for pure compounds (Cos et al., 2006). We expect the presence of pinocembrin-7-neohesperidoside and spinasterol in $A$. carambola leaves may result in excellent antifungal activity against C. albicans. However, the mechanisms behind the inhibitory should be evaluated afterward. Overall, the proposed mechanisms underlying the antifungal activity are either by inhibiting biofilm or filamentation of the fungi or by interrupting the homeostasis process. From the $\mathrm{CV}$ assay, there is a possibility that the ethyl acetate fraction of $A$. carambola leaves inhibits the biofilm formation, which corresponds to the CV assay. However, this finding needs to be confirmed by microscopic in order to see the hyphae and filamentation formation. Another possible mechanism is through the disruption of homeostasis. In this matter, the flavonoid derivatives and compounds presented in A. carambola leaves could inhibit the nucleic acid synthesis through the DNA gyrase. The inhibitory action is possibly initiated by the 
intercalation between B-ring in flavonoids and 3-OH in the nucleic acid- base, which results in the disruption of nucleic acid synthesis (Mori et al., 1987). Therefore, further experiments are needed to confirm the exact inhibitory mechanism of $A$. carambola (leaves) ethyl acetate extract against $C$. albicans.

\section{CONCLUSION}

In our preliminary results, $A$. carambola (leaves) ethyl acetate extract showed inhibitory activity on $C$. albicans growth, suggesting that $A$. carambola is a potential source for antiCandida drug development. Further investigations through other techniques such as molecular approaches are needed to explore in more detail the inhibitory properties of $A$. carambola against $C$. albicans. Identification of active compound(s) and elucidation of the mechanism of its action would be part of our future studies.

\section{ACKNOWLEDGMENTS}

None.

\section{AUTHORS' CONTRIBUTIONS}

M.I.I. : Designed and performed the experiment, wrote and drafted the manuscript.

R.R. : Performed the experiment and wrote the manuscript.

N.P : Performed the experiment and wrote the manuscript.

F.H.M : Performed the experiment.

M.R : Wrote and revised the manuscript.

B.E : Contributed material, designed the experiment, and revised the manuscript.

\section{CONFLICT OF INTEREST}

The authors have no conflict of interest to declare.

\section{FUNDING}

This research is funded by the Directorate of Research and Community Engagement Universitas Indonesia, via IRP grant number 015/UN2.F15.D/HKP.05.00/2019.

\section{ETHICAL APPROVALS}

This study does not involve experiments on animals or human subjects.

\section{PUBLISHER'S NOTE}

This journal remains neutral with regard to jurisdictional claims in published institutional affiliation.

\section{REFERENCES}

Cos P, Vlietinck AJ, Berghe DV, Maes, L. Anti-infective potential of natural products: how to develop a stronger in vitro proof-of-concept. J Ethnopharmacol, 2006; 106:290-302.

Cushnie TPT, Lamb, AJ. Antimicrobial activity of flavonoids. Int J Antimicrob Agents, 2005; 26:343-56.

Fidel PL Jr. Vaginal candidiasis: review and role of local mucosal immunity. AIDS Patient Care STDs, 1998; 12:359-66.

Governa P, Cusi MG, Borgonetti V, Sforcin JM, Terrosi C, Baini G, Miraldi E, Biagi M. Beyond the biological effect of a chemically characterized poplar propolis: antibacterial and antiviral activity and comparison with flurbiprofen in cytokines release by LPS-stimulated human mononuclear cells. Biomedicines, 2019; 7:73.
Kumar S, Kumar V, Prakash OM. Pharmacognostic study and anti-inflammatory activity of Callistemon lanceolatus leaf. Asian Pac J Trop Biomed, 2011; 1:177-81.

Li Y, Sun L, Lu C, Gong Y, Li M, Sun S. Promising antifunga targets against Candida albicans based on ion homeostasis. Front Cell Infect Microbiol, 2018; 8:286.

Lightbown JW, Kogut M, Uemura K. The international standard for nystatin. Bull World Health Organ, 1963; 29:87-94.

Lopes G, Pinto E, Salgueiro L. Natural products: an alternative to conventional therapy for dermatophytosis? Mycopathologia, 2017; 182:143-67.

Meiller TF, Hube B, Schild L, Shirtliff ME, Scheper MA, Winkler R, Ton A, Jabra-Rizk MA. A novel immune evasion strategy of Candida albicans: proteolytic cleavage of a salivary antimicrobial peptide. PLoS One, 2009; 4:e5039.

Mewara D, Tamakuwala H, Desai B. Antifungal activity and phytochemical screening from leaf extract of Manilkara zapota and Averrhoa carambola. BMR Phytomed, 2017; 3:1-9.

Monteiro CA, Santos JRA. Phytochemicals and their antifungal potential against pathogenic yeasts. In: Phytochemicals in Human Health, IntechOpen, 2019.

Mori A, Nishino C, Enoki N, Tawata S. Antibacterial activity and mode of action of plant flavonoids against Proteus vulgaris and Staphylococcus aureus. Phytochemistry, 1987; 26:2231-4.

Nabilah, Elya B, Djajadisastra J. Lipoxygenase inhibitory assay of Averrhoa carambola L. leaves extract. Int J ChemTech Res, 2017; $10: 342-7$

Naglik JR, Challacombe SJ, Hube B. Candida albicans secreted aspartyl proteinases in virulence and pathogenesis. Microbiol Mol Biol Rev, $2003 ; 67: 400-28$

Newman DJ, Cragg GM. Natural products as sources of new drugs from 1981 to 2014. J Nat Prod, 2016; 79:629-31.

Pierce CG, Lopez-Ribot JL. Candidiasis drug discovery and development: new approaches targeting virulence for discovering and identifying new drugs. Expert Opin Drug Discov, 2013; 8:1117-26.

Poongodi T, Nazeema TH. In vitro cytotoxicity, phytochemistry and GC-MS analysis of Averrhoa carambola (leaf) against MCF-7 breast cancer cell line. Int J Curr Res, 2016; 8:29044-8.

Ragasa CY, Tsai PW, Shen CC. Antimicrobial terpenoids from Erigeron sumatrensis. NCRP Res J, 2009; 10(1):27-32.

Ramawat KG, Merillon JM. Bioactive molecules and medicinal plants. Springer-Verlag Berlin Heidelberg, Berlin, Germany, pp 352-3, 2008

Rasul A, Millimuono FM, Eltayb WA, Ali M, Li J, Li X. Pinocembrin: a novel natural compound with versatile pharmacological and biological activities. Biomed Res Int, 2013; 2013:9.

Redding SW, Zellars RC, Kirkpatrick WR, McAtee RK, Caceres MA, Fothergill AW, Lopez-Ribot JL, Bailey CW, Rinaldi MG, Patterson TF. Epidemiology of oropharyngeal Candida colonization and infection in patients receiving radiation for head and neck cancer. J Clin Microbiol, 1999; 37:3896-900.

Rosenfeld JA. Vaginitis. In: Handbook of Women's Health, 2nd edition, Cambridge University Press, Cambridge, UK, pp 161-6, 2009.

Salehi B, Venditti A, Sharifi-Rad M, Kregiel D, Sharifi-Rad J, Durazzo A, Lucarini M, Santini A, Souto EB, Novellino E, Antolak H, Azzini E, Setzer WN, Martins N. The therapeutic potential of apigenin. Int J Mol Sci, 2019; 20:1305.

Santos GCO, Vasconcelos CC, Lopes AJO, Cartágenes MSS, Filho AKDB, Nascimento FRF, Ramos RM, Pires ERRB, Andrade MS, Rocha FMG, Monteiro CA. Candida infections and therapeutic strategies: Mechanisms of action for traditional and alternative agents. Front Microbiol, 2018; 9:1351.

Scholz EP, Zitron E, Katus HA, Karle CA. Cardiovascular ion channels as a molecular target of flavonoids. Cardiovasc Ther, 2010; 28:46-52.

Whaley SG, Berkow EL, Rybak JM, Nishimoto AT, Barker KS, Rogers PD. Azole antifungal resistance in Candida albicans and emerging non-albicans Candida species. Front Microbiol, 2017; 7:2173. 
Yunarto N, Sulistyaningrum, N. Quantitative analysis of bioactive compounds in extract and fraction of star fruit (Averrhoa carambola L.) leaves using high performance liquid chromatography. J Kefarmasian Indones, 2017; 7:26-33.

Xu X, Xie H, Hao J, Jiang Y, Wei X. Flavonoid glycosides from the seeds of Litchi chinensis. J Agric Food Chem, 2011; 59(4):1205-9.

Zida A, Bamba S, Yacouba A, Ouedraogo-Traore R, Guiguemdé RT. Anti- Candida albicans natural products, sources of new antifungal arugs: a review. J Mycol Med, 2017; 27:1-19.
How to cite this article:

Irianti MI, Elya B, Rahmasari R, Puspitasari N, Maharani FH, Raekiansyah M. Averrhoa carambola leaf from Depok, West Java, Indonesia: Phytochemistry characterization and prospective anti-candidiasis activity. J Appl Pharm Sci, 2022; 12(01):199-207. 